\title{
Fit assessment of two different anatomically contoured distal femur plate sets on cadaveric bones
}

\author{
İki farklı anatomik şekillendirilmiş distal femur plak setinin kadavra kemikleriyle \\ uyumunun değerlendirilmesi
}

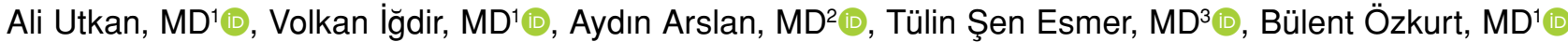 \\ 1'Department of Orthopedics and Traumatology, University of Health Sciences, Ankara Numune Training and Research Hospital, Ankara, Turkey \\ ${ }^{2}$ Department of Orthopedics and Traumatology, İstanbul Gelişim University Special Elit İstanbul Medical Center, Istanbul, Turkey \\ ${ }^{3}$ Department of Anatomy, Ankara University Faculty of Medicine, Ankara, Turkey
}

\begin{abstract}
Objectives: This study aims to investigate the fitness of two anatomic distal femoral plates with cadaveric femurs and to show whether current plates optimally match each femur.
\end{abstract}

Materials and methods: Two different sets of plates with five, seven and nine shaft holes were applicated on 62 cadaveric femurs. Ball clay was molded onto the entire inner surfaces of the plates and then the plates were fixed to the bones using two self-locking nylon cable zip ties. The volume of ball clay sandwiched in between the plate and bone was calculated and used as a quantitative fit parameter. Data of each plate were analyzed separately.

Results: Using Double Medical Technology Incorporated ${ }^{\mathrm{TM}}$ plates, the mean plate to bone volumes were calculated as $8.4 \mathrm{~mL}$ (range, 5-14 mL), $10.0 \mathrm{~mL}$ (range, 6-17 mL), and $13.1 \mathrm{~mL}$ (range, 7-25 mL) in five, seven and nine-hole plates, respectively. Using Zimmer Biomet Incorporated ${ }^{\mathrm{TM}}$ plates, the mean volumes were $10.5 \mathrm{~mL}$ (range, 6-21 mL), $12.7 \mathrm{~mL}$ (range, 7-22 $\mathrm{mL}$ ) and $16.3 \mathrm{~mL}$ (range, $8-30 \mathrm{~mL}$ ) in five, seven and nine-hole plates, respectively. Within each group, the measurements were significantly correlated positively with femoral length.

Conclusion: Optimal fit may not be achieved in each femur using current distal femoral plate implant sets. Thus additional sizes of plates should be supplied in the implant sets.

Keywords: Cadaveric dry femur bone, congruency of locking plates, distal femur plate, fit assessment parameter, plate bone fit, precontoured plate fit, quantitative fit parameter.

\section{$\ddot{O Z Z}$}

Amaç: $\mathrm{Bu}$ çalışmada iki anatomik distal femur plağının kadavra femurlarıyla uyumluluğu araştırıldı ve mevcut plakların her femura en iyi şekilde uyup uymadığı gösterildi.

Gereç ve yöntemler: Gövdesinde beş, yedi ve dokuz deliği olan iki farklı plak seti 62 kadavra femuruna uyguland. Plakların tüm iç yüzeyleri seramik çamuruyla sıvandı, sonra plaklar iki adet kendinden kilitli naylon kablo bağ kullanılarak kemiklere sabitlendi. Plak ve kemik arasında sıkıştırılan seramik çamurunun hacmi hesaplanarak nicel uyum parametresi olarak kullanıldı. Her plağın verileri ayrı ayrı analiz edildi.

Bulgular: Double Medical Technology Incorporated $^{\mathrm{TM}}$ plakları kullanıldığında, plak ile kemik arasındaki hacim ortalamaları beş, yedi ve dokuz delikli plaklarda sırasıyla $8.4 \mathrm{~mL}$ (dağılım, 5-14 mL), $10.0 \mathrm{~mL}$ (dağılım, 6-17 mL) ve $13.1 \mathrm{~mL}$ (dağılım, 7-25 mL) olarak hesaplandı. Zimmer Biomet Incorporated ${ }^{\mathrm{TM}}$ plakları kullanıldığında, hacim ortalamaları beş, yedi ve dokuz delikli plaklarda sırasıyla $10.5 \mathrm{~mL}$ (dağılım, 6-21 mL), $12.7 \mathrm{~mL}$ (dağılım, 7-22 mL) ve $16.3 \mathrm{~mL}$ (dağılım, 8-30 mL) idi. Her grup içinde, ölçümler femur uzunluğu ile pozitif olarak anlamlı şekilde bağıntılı idi.

Sonuç: Mevcut distal femur plağı implant setleri kullanılarak her femurda en iyi uyum elde edilemeyebilir. Bu nedenle, implant setlerinde ilave boyutlarda plaklar sağlanmalıdır.

Anahtar sözcü̈kler: Kadavra kuru femur kemiği, kilitli plakların uygunluğu, distal femur plağı, uyum değerlendirme parametresi, plak kemik uyumu; önceden şekillendirilmiş plak uyumu, nicel uyum parametresi.

Received: January 25, 2019 Accepted: May 14, 2019 Published online: May 27, 2019

Correspondence: Ali Utkan, MD. SBÜ Ankara Numune Eğitim ve Araştırma Hastanesi Ortopedi ve Travmatoloji Kliniği, 06530 Çankaya, Ankara, Turkey. Tel: +90533 - 3370111 e-mail: utkana@yahoo.com 
Treatment of distal femoral fractures by minimally invasive percutaneous plate osteosynthesis (MIPPO) using anatomically contoured plates without direct exposure of the fracture fragments leads to better clinical outcomes compared with the traditional open reduction techniques; however, these submuscular plating methods are considered technically challenging. ${ }^{[1,2]}$ Fitting the plate in the correct position while completion of alignment in all three axes can be cumbersome even to the experienced surgeons, and technical errors are not forgiving. ${ }^{[3]}$ Reduction without using the plate is particularly challenging when performing minimally invasive surgery since bone exposure is very limited. ${ }^{[4]}$ It requires various traction procedures, various percutaneous reduction clamps, K-wires to manipulate the bone fragments and provisional pinning. Applying a properly contoured plate to the diaphyseal fragment automatically reduces the metaphyseal fracture. This technique corrects small displacements and angulation while maintaining stability as the reduction occurs. ${ }^{[5]}$ A well-fitting plate can act as a template for anatomical reduction, as well as reduce implant prominence in the region where the soft tissue covering is thin. ${ }^{[4]}$ Also, in the literature, there are recommendations indicating that the distance between the plate and the bone should be as small as possible to increase its mechanical stability though locking plates do not need to be in full contact with the bone. ${ }^{[6,7]}$

Manufacturers provide different plate lengths for left and right femurs. These are all unisize plates intended to fit every adult femur. The development of patient specific plates is reported but this is a very complex and an expensive procedure. ${ }^{[8-10]}$ The variations in bone morphology may cause poorly fitting plates in some patients and the surgeon can be misled by this mismatch resulting with malalignment unless the surgeon manually contours the plate accordingly. ${ }^{[11]}$ The chances of malunion in distal femur locked plating in inexperienced hands are higher as the reduction of comminuted fractures is difficult. ${ }^{[12]}$ We believe a unisize plate does not fit optimally in every patient as there are significant differences between individuals and the management of the fracture would be more appropriate if there were additional sizes of the plates.

In the literature, there are many experimental biomedical engineering studies that used expensive and complex methods to place the plates virtually and calculated the mean or the maximum distance or the volume between the plate surface and underlying bone surface in term of fit assessment. ${ }^{[13-19]}$ We proposed a novel method which is inexpensive and simple to find the volume between the cadaver bone and the plate placed, using a similar technique in a surgical procedure so as to assess a quantitative fit parameter. ${ }^{[20]}$ This method is used to investigate the plate bone congruence with the two most commonly used plate sets from two different companies in our clinic for distal femoral fractures. Therefore, in this study, we aimed to investigate the fitness of two anatomic distal femoral plates with cadaveric femurs and to show whether current plates optimally match each femur.

\section{MATERIALS AND METHODS}

This study was conducted at Ankara Numune Training and Research Hospital between April 2018 and June 2018. Two different distal femur plate sets obtained from two different companies, one from an authorized dealer of 'Double Medical Technology' Incorporated and the other from 'Zimmer Biomet' Incorporated were used. According to their promotional brochures, they are made of titanium and both of them are anatomically contoured to create a strong interface between the plate and the bone. However, the proximal head parts, the screw holes and the plate undersurfaces have different shapes. The other plates on the market often resemble one of them. Although plates with five, seven, nine, 11, and 13 holes for right and left femurs exist, to our knowledge, those with 11 and 13 holes were not tested, as they are seldom used in clinical practice. All available intact dry adult cadaver femurs obtained from Anatomy Department of Ankara University Faculty of Medicine were used. There were 30 right and 32 left femurs and they were assumed to represent a normal adult body size and gender distribution. The approval by the ethical review board is not needed for this study because the bones belong to unknown people without any inheritor and they were donated for educational purposes.

The length and bicondylar breadth (the distance between the two epicondyles) were measured for each femur. The maximum length of the femur was taken from the most superior point of the head of the femur to the most inferior point of the medial condyle by using a tape measure. Calipers obtained from hemiarthroplasty surgical instrumentation set were used to measure the bicondylar breadth.

Plates with five, seven and nine shaft holes, therefore, six right-sided and six left-sided plates were tested. All plates were applied to match the bones, thus the right-sided plates were applied to the right femur and the left-sided plates were applied to the left femur. A ready-to-use ball clay packed in vacuumed 
bags (Eczacibaşı Esan Esc-1 beyaz vakum çamur, Istanbul, Turkey) were applied to assess the volume between the plate and underlying bone surface. In each case, a piece of ball clay was molded onto the entire inner surface of the plate and then the distal part of the plate was placed on the distal femur in a most fitted position as was implemented in the actual surgery since soft tissue over the lateral condyle is thin necessitating good matching of the distal part during surgery. Subsequently, the proximal part of the plate was centered over the bone so that diaphyseal screws would pass through the two cortices. The plate was compressed and fixed to the bone using two $3.2 \mathrm{~mm}$ self-locking nylon cable zip ties, as opposed to using screw fixation in real surgery, where unlocked screws would press the plate onto the bone and the clay is squeezed out. The excess clay was wiped out as done to the cement during an arthroplasty procedure (Figure 1a-c). Then, whether all holes were suitable for locked screw placement or not was observed.

The nylon cables were cut down and the plate was removed. The clay between the bone and the plate was scraped completely and rolled into a ball (Figure 1d). The clay which filled the holes of plates were untouched. This ball was dropped into a graduated cylinder filled partially with water. The volume of the overflowed water, which was presumed to be equal to the volume of the clay ball, was calculated. The same bone was used repeatedly to test all plates, thus each bone was used six times to test each plate. However, the data were analyzed for individual plates distinctly; i.e., volumes between each plate and 62 femurs were analyzed considering femur biometric measurements.

\section{Statistical analysis}

Statistical analysis was performed using the IBM SPSS version 21.0 software (IBM Corp., Armonk, NY, USA). The Shapiro-Wilk test was used to check whether the data were normally distributed. The relationship between biometric variables was computed by Pearson correlation test as the data showed a normal distribution. Spearman correlation test was used for volume measurements versus length or breadth as the data did not show a normal distribution.

\section{RESULTS}

The mean femoral length was $43.09 \pm 3.07 \mathrm{~cm}$ (range, 36-52 $\mathrm{cm}$ ) and the bicondylar breadth was $7.77 \pm 0.58 \mathrm{~cm}$ (range, 6.7-8.8 cm). Both had normal distribution. As expected, there were significant correlations between the lengths versus bicondylar breadths $(\mathrm{p}=0.0001)$.
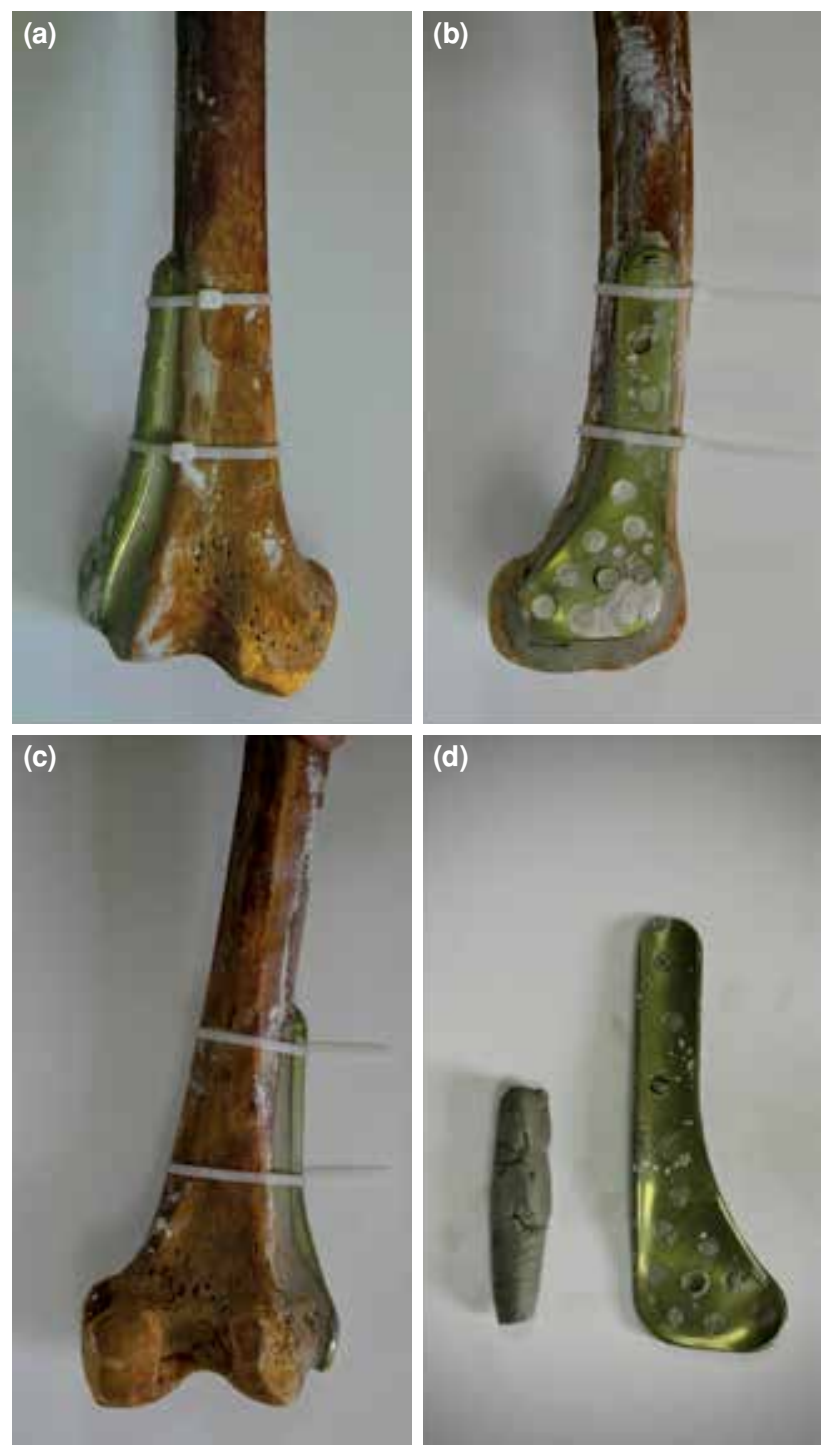

Figure 1. A five-hole Zimmer Biomet Incorporated plate placed in most fitted position as is implemented in actual surgery. (a) Anterior view. (b) Lateral view. (c) Posterior view. (d) Clay between bone and plate was scraped completely and rolled into a ball.

The amount of the clay, which represented the volume underneath the plate, was not uniformly distributed in any case and there were at least two bare points indicating exact contact points between plate and bone. The mean plate to bone volume was $8.4 \mathrm{~mL}$ (range, 5-14 $\mathrm{mL}$ ) in the five-hole plate group, $10.0 \mathrm{~mL}$ (range, 6-17 $\mathrm{mL}$ ) in the seven-hole plate group and $13.1 \mathrm{~mL}$ (range, 7-25 $\mathrm{mL}$ ) in the nine-hole plate group when Double Medical Technology Incorporated $^{\mathrm{TM}}$ plates were used. When Zimmer Biomet Incorporated ${ }^{\mathrm{TM}}$ plates were used, the mean volumes for the five-hole plate group was $10.5 \mathrm{~mL}$ (range, 6-21 mL), the seven-hole plate group was 
TABLE I

Descriptive statistics for volume measurements $(\mathrm{mL})$

\begin{tabular}{lcc}
\hline Plates & Mean \pm SD & Min-Max \\
\hline Double medical technology incorporated plate & & \\
5-hole plates & $8.36 \pm 2.2283$ & $5-14$ \\
7-hole plates & $10.01 \pm 2.736$ & $6-17$ \\
9-hole plates & $13.10 \pm 3.861$ & $7-25$ \\
Zimmer Biomet incorporated plate & & \\
5-hole plates & $10.48 \pm 3.3353$ & $6-21$ \\
7-hole plates & $12.66 \pm 3.526$ & $7-22$ \\
9-hole plates & $16.25 \pm 5.307$ & $8-30$ \\
\hline
\end{tabular}

SD: Standard deviation; Min: Minimum; Max: Maximum.

TABLE II

Spearman correlation tests

\begin{tabular}{lcc}
\hline & Spearman correlation coefficient & $p$ \\
\hline DMT 5-hole vs. femur length & 0.252 & $0.048^{*}$ \\
DMT 7-hole vs. femur length & 0.321 & $0.031^{*}$ \\
DMT 9-hole vs. femur length & 0.292 & $0.033^{*}$ \\
Z-B 5-hole vs. femur length & 0.318 & $0.03^{*}$ \\
Z-B 7-hole vs. femur length & 0.293 & $0.021^{*}$ \\
Z-B 9-hole vs. femur length & 0.354 & $0.005^{*}$ \\
DMT 5-hole vs. bicondylar breadth & 0.258 & $0.043^{*}$ \\
DMT 7-hole vs. bicondylar breadth & 0.002 & 0.989 \\
DMT 9-hole vs. bicondylar breadth & 0.065 & 0.614 \\
Z-B 5-hole vs. bicondylar breadth & 0.258 & $0.043^{*}$ \\
Z-B 7-hole vs. bicondylar breadth & 0.233 & 0.061 \\
Z-B 9-hole vs. bicondylar breadth & 0.254 & $0.046^{*}$ \\
\hline
\end{tabular}

DMT: Double Medical Technology Incorporated plates; Z-B: Zimmer Biomet Incorporated plates; ${ }^{\text {Significant. }}$

$12.7 \mathrm{~mL}$ (range 7-22) and the nine-hole plate group was $16.3 \mathrm{~mL}$ (range, 8-30 mL). Descriptive statistics for volume measurements are given in Table I and the results of Spearman correlation tests are given in Table II.

Only in one femur, the two holes corresponding to the middle part of nine-hole plates were not suitable for screw application due to excessive anterior bowing. Also, in another femur, there was an angulation at coronal plane where the distance between the proximal part of the plate and the bone was increased after the plate was applicated, leaving us to apply the proximal two screws through the bone 60 degrees (Figure 2a-c). However, if these events had been in the real osteosynhthesis procedure, sufficient fixation could have been obtained in all of them.

\section{DISCUSSION}

Each manufacturer provides slightly different shaped, plates with different shaft lengths; however, these are simply unisize plates designed to be used in every patient. The development of a patientspecific plate is a very complex and an expensive procedure. ${ }^{[8-10]}$ Wang et al. ${ }^{[21]}$ evaluated eight anatomical femur parameters in 100 femur samples and designed three sizes of anatomical plates for femur and proposed that one should be selected correspondingly according to femur parameters. In our clinic, we use commercially available unisize plates, which are designed based on mean anthropometric data, and choose the plate lengths according to fracture characteristics such as fracture types and lengths. In daily practice, it is hard to try different plates from different companies on the same patient during 

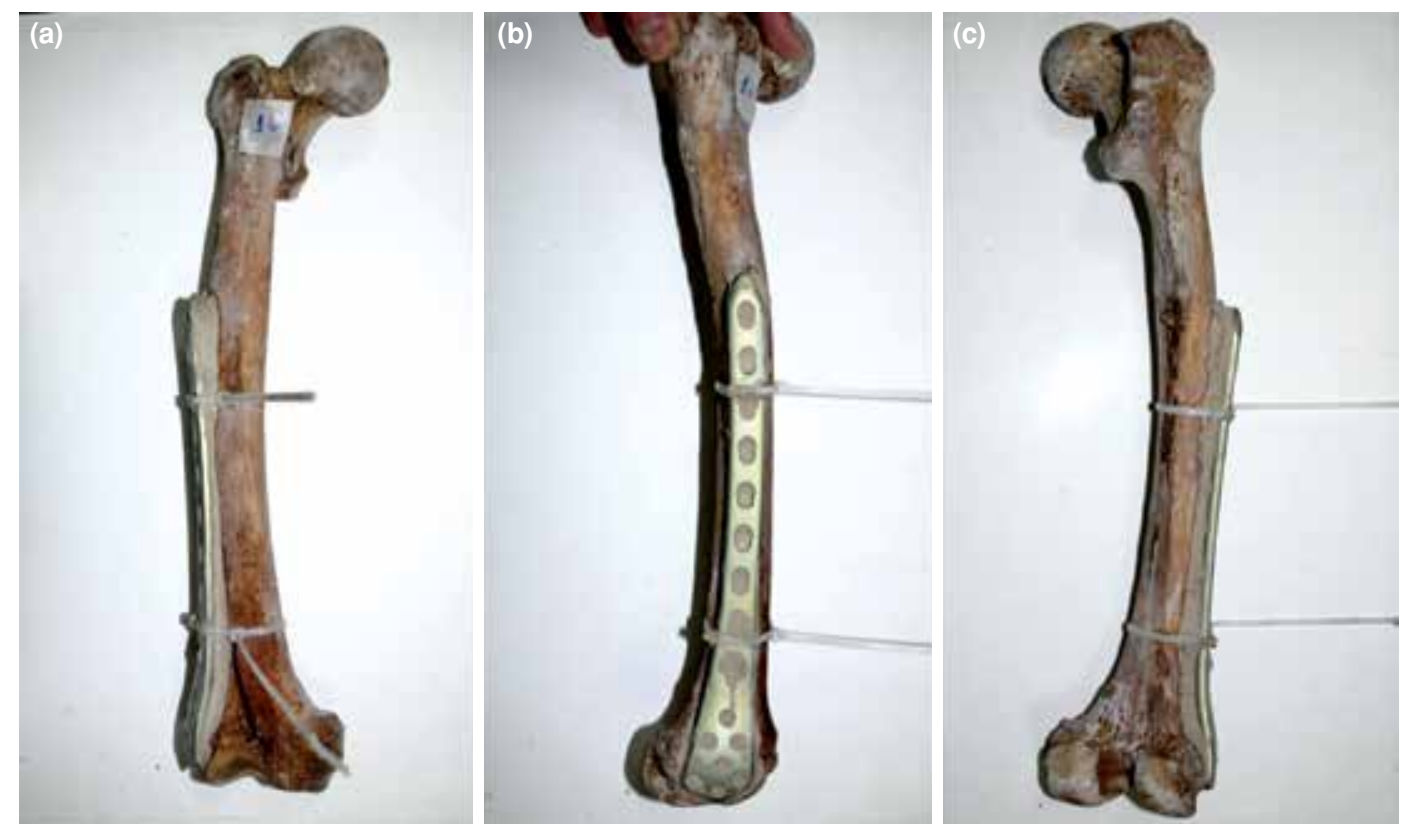

Figure 2. A nine-hole Double Medical Technology Incorporated plate placed on a femur having coronal angulation. (a) Anterior view. (b) Lateral view. (c) Posterior view.

operation to find the best fitting one. Thus we aimed to explore if additional sizes of plates should be added into the same plate set.

We proposed a novel method to quantify the fit of plates on cadaveric bones. Several definition methods for the fit optimization of a precontoured fracture fixation plate for a given bone data set have been presented in the literature ${ }^{[13-19]}$ In most of them, the fitting of the plate to the bone is conducted entirely in a virtual environment utilizing computer graphical methods and three-dimensional bone and plate models based on computer tomography scans. In contrast to these studies in which the computer places the plate in the best position, in our study, the plate was placed over the bone as was implemented in actual surgery.

The mean distance between the plate surface and the underlying bone surface, ${ }^{[15-17]}$ the maximum distance between the plate and the underlying bone surface, ${ }^{[18,19]}$ and also the volume between the plate and underlying bone surface ${ }^{[13]}$ were used as fit assessment parameters. Furthermore, qualitative evaluation was used in some studies. In their studies, Giannicola et al. ${ }^{[22,23]}$ evaluated the congruency between an anatomic plate and proximal radius on cadaveric bones by two independent observers and congruence was classified as good, moderate or poor. In this study, the volume of free space between the plate and bone was used as a criteria. Each plate was tried on 62 femurs. The readyto-use ball clay, which was used to find this volume, is relatively cheap, easy to apply and can be cleaned off from the bones and plates swiftly without giving any damage. The bones were returned to the anatomy department without harm.

The estimated maximum volume values for distinct plates were at least 2.8 (and at most 3.8) times more than minimum volume values. We can conclude that mismatching existed for some platebone combines. Hwang et al. ${ }^{[1]}$ demonstrated that the mismatch of anatomically pre-shaped locking plate on the Asian femurs could lead to malalignment in the minimally invasive plating of distal femoral fractures on cadaveric bones. Mismatch was found at the proximal of the plate with an mean distance of $11.36 \mathrm{~mm}$ at the tip of the plate and it was reported that an attempt to fit the plate proximally might cause valgus malalignment. We found this problem in one of the femurs presented at Figure 2. Batista et al. ${ }^{[3]}$ reported $27 \%$ failure rate in the initial reduction with axis deviation and linked this problem to the difficulty in adapting an implant sized to a population ethnically very distinct from theirs.

Although sufficient fixation would have been obtained with all of the plates if it had been a real operation, the volume measurements within each plate group were significantly correlated positively with femoral length. When femur breadth (width) is considered, interestingly, only five-hole plates significantly correlated for both brands. The axial 
slices of the femur that are somewhat trapezoidal in shape are not uniform throughout its length and a relatively flat plate does not match well. It seems that plates fit to small femurs comparatively better than the large ones.

This study has some limitations. As the contour and surface areas of the distal part of the two plates were different, it would have been better if the volumes underneath the distal part and the shaft part of the plates were determined separately. It is not fair to conclude that one type of plate we tested had better congruence than the other, as such, unless a way of an adjustment co-efficient, i.e., dividing the entire volume by the surface area of the plate, is used. Furthermore, one cannot know how the results would be affected unless at least another size is manufactured and tested. Still, we believe that our study provides accurate data sufficient to compare a chosen plate placed on different cadaveric bones. Furthermore, this proposed method may be used as a quantitative fit parameter in studies on cadaveric bones, while needing improvement to compare different designs.

In conclusion, optimal fit might not be attained in each femur by using the existing unisize distal femoral plate sets. Therefore, additional sizes that match diverse femoral dimensions should be provided in the available plate sets.

\section{Acknowledgement}

We wish to thank Emel Arslan for her assistance with the statistics used in this study.

\section{Declaration of conflicting interests}

The authors declared no conflicts of interest with respect to the authorship and/or publication of this article.

\section{Funding}

The authors received no financial support for the research and/or authorship of this article.

\section{REFERENCES}

1. Gill S, Mittal A, Raj M, Singh P, Singh J, Kumar S. Extra Articular Supracondylar Femur Fractures Managed with Locked Distal Femoral Plate or Supracondylar Nailing: A Comparative Outcome Study. J Clin Diagn Res 2017;11:19-23.

2. Piétu G, Ehlinger M. Minimally invasive internal fixation of distal femur fractures. Orthop Traumatol Surg Res 2017;103:S161-9.

3. Batista BB, Salim R, Paccola CA, Kfuri Junior M. Internal fixators: a safe option for managing distal femur fractures? Acta Ortop Bras 2014;22:159-62.

4. Bel JC. Pitfalls and limits of locking plates. Orthop Traumatol Surg Res 2019;105:103-9.

5. Pesantez R. Surgical reduction. In: Buckley RE, Moran GM, Apivatthakakul T, editors. AO principles of fracture mamagement. 3rd ed. Stuttgart; Thieme Verlag; 2018. p. 117-36.

6. Ahmad M, Nanda R, Bajwa AS, Candal-Couto J, Green S,
Hui AC. Biomechanical testing of the locking compression plate: when does the distance between bone and implant significantly reduce construct stability? Injury 2007;38:358-64.

7. Stoffel K, Dieter U, Stachowiak G, Gächter A, Kuster MS. Biomechanical testing of the LCP--how can stability in locked internal fixators be controlled? Injury 2003;34:11-9.

8. Chen X, He K, Chen Z, Wang L. A parametric approach to construct femur models and their fixation plates. Biotechnol Biotec Eq 2016;30:529-37.

9. Chen X, He K, Chen Z. A novel computer-aided approach for parametric investigation of custom design of fracture fixation plates. Comput Math Methods Med 2017;2017:7372496

10. Wang, L, He, K, Chen, Z, Yang, Y. A design method for orthopedic plates based on surface features. J Mech Design 2017;139:024502.

11. Hwang JH, Oh JK, Oh CW, Yoon YC, Choi HW. Mismatch of anatomically pre-shaped locking plate on Asian femurs could lead to malalignment in the minimally invasive plating of distal femoral fractures: a cadaveric study. Arch Orthop Trauma Surg 2012;132:51-6.

12. Pramod G, Vijayakumar AV. Study on the complications of locking compression plate used for fracture lower end of femur. Int J Orthop Sci 2016;2:146-9.

13. Goyal KS, Skalak AS, Marcus RE, Vallier HA, Cooperman DR. Analysis of anatomic periarticular tibial plate fit on normal adults. Clin Orthop Relat Res 2007;461:245-57.

14. Hazreen H, Beat S, Michael S, Yuan Tong G, Prasad KY. Quantitative fit assessment of a precontoured fracture fixation plate: Its automation and an investigation on the borderline cases. Adv Mater Res 2011;339:685-9.

15. Huang JI, Toogood P, Chen MR, Wilber JH, Cooperman DR. Clavicular anatomy and the applicability of precontoured plates. J Bone Joint Surg [Am] 2007;89:2260-5.

16. Kozic N, Weber S, Büchler P, Lutz C, Reimers N, González Ballester MA, et al. Optimisation of orthopaedic implant design using statistical shape space analysis based on level sets. Med Image Anal 2010;14:265-75.

17. Park AY, DiStefano JG, Nguyen TQ, Buckley JM, Montgomery WH, et al. Congruency of scapula locking plates: implications for implant design. Am J Orthop (Belle Mead NJ) 2012;41:E53-6.

18. Schulz AP, Reimers N, Wipf F, Vallotton M, Bonaretti S, Kozic N, et al. Evidence Based Development of a Novel Lateral Fibula Plate (VariAx Fibula) Using a Real CT Bone Data Based Optimization Process During Device Development. Open Orthop J 2012;6:1-7.

19. Schmutz B, Wullschleger ME, Kim H, Noser H, Schütz MA. Fit assessment of anatomic plates for the distal medial tibia. J Orthop Trauma 2008;22:258-63.

20. Atik OŞ. Which articles do we prefer to publish? Eklem Hastalik Cerrahisi 2018;29:1.

21. Wang L, He K, Chen Z. Statistical analyses of femur parameters for designing anatomical plates. Comput Math Methods Med 2016;2016:1247560.

22. Giannicola G, Manauzzi E, Sacchetti FM, Greco A, Bullitta G, Vestri A, et al. The applicability of the Mayo Clinic congruent radial head plate: cadaveric study. Musculoskelet Surg 2011;95:1-5.

23. Giannicola G, Manauzzi E, Sacchetti FM, Greco A, Bullitta $G$, Vestri $A$, et al. Anatomical variations of the proximal radius and their effects on osteosynthesis. J Hand Surg [Am] 2012;37:1015-23. 